\title{
Review \\ Functional Role of miR-155 in the Pathogenesis of Diabetes Mellitus and Its Complications
}

\author{
Stanislovas S. Jankauskas ${ }^{1,2} \oplus$, Jessica Gambardella ${ }^{1,2,3}$, Celestino Sardu ${ }^{4}$, Angela Lombardi $^{1}$ \\ and Gaetano Santulli 1,2,3,*(D) \\ 1 Department of Medicine, Fleischer Institute for Diabetes and Metabolism (FIDAM), Einstein-Mount Sinai \\ Diabetes Research Center (ES-DRC), Albert Einstein College of Medicine, New York, NY 10461, USA; \\ stanislovas.jankauskas@einsteinmed.org (S.S.J.); jessica.gambardella@einsteinmed.org (J.G.); \\ angela.lombardi@einsteinmed.org (A.L.) \\ 2 Department of Molecular Pharmacology, Wilf Family Cardiovascular Research Institute, Einstein Institute for \\ Aging Research, Albert Einstein College of Medicine, New York, NY 10461, USA \\ 3 International Translational Research and Medical Education Consortium (ITME), Department of Advanced \\ Biomedical Science, "Federico II" University, 80131 Naples, Italy \\ 4 Department of Advanced Medical and Surgical Sciences, University of Campania "Luigi Vanvitelli", \\ 80138 Naples, Italy; celestino.sardu@unicampania.it \\ * Correspondence: gsantulli001@gmail.com
}

Citation: Jankauskas, S.S.;

Gambardella, J.; Sardu, C.; Lombardi,

A.; Santulli, G. Functional Role of miR-155 in the Pathogenesis of Diabetes Mellitus and Its Complications. Non-coding RNA 2021,

7,39. https://doi.org/10.3390/ ncrna7030039

Academic Editor: George A Calin

Received: 31 May 2021

Accepted: 3 July 2021

Published: 7 July 2021

Publisher's Note: MDPI stays neutral with regard to jurisdictional claims in published maps and institutional affiliations.

Copyright: (c) 2021 by the authors. Licensee MDPI, Basel, Switzerland. This article is an open access article distributed under the terms and conditions of the Creative Commons Attribution (CC BY) license (https:// creativecommons.org/licenses/by/ $4.0 /)$.

\begin{abstract}
Substantial evidence indicates that microRNA-155 (miR-155) plays a crucial role in the pathogenesis of diabetes mellitus (DM) and its complications. A number of clinical studies reported low serum levels of miR-155 in patients with type 2 diabetes (T2D). Preclinical studies revealed that miR-155 partakes in the phenotypic switch of cells within the islets of Langerhans under metabolic stress. Moreover, miR-155 was shown to regulate insulin sensitivity in liver, adipose tissue, and skeletal muscle. Dysregulation of miR-155 expression was also shown to predict the development of nephropathy, neuropathy, and retinopathy in DM. Here, we systematically describe the reports investigating the role of miR-155 in DM and its complications. We also discuss the recent results from in vivo and in vitro models of type 1 diabetes (T1D) and T2D, discussing the differences between clinical and preclinical studies and shedding light on the molecular pathways mediated by miR-155 in different tissues affected by DM.
\end{abstract}

Keywords: $\beta$-cells; diabetes; epigenetics; inflammation; insulin; islets; MafB; metabolic syndrome; micro-RNA; miR-155; NF-кB; NRF2; PBMC

\section{Introduction}

The pandemic of diabetes mellitus (DM) represents one of the most important longterm challenges for healthcare systems around the globe [1]. The International Diabetes Federation (IDF) has estimated that DM will affect $~ 642$ million people by 2040 [2]. DM is accountable for $6.8 \%$ of global mortality in an age group of 20-79 years old and constitutes a major cause of reduced life expectancy [3-5]. Approximately 10\% of DM patients suffer from type 1 diabetes (T1D), caused by an autoimmune destruction of pancreatic $\beta$-cells [6,7], while 90\% of DM cases refer instead to type 2 diabetes (T2D), whose main risk factors are obesity, lack of physical exercise, and smoking [1,8]. Several clinical trials have demonstrated that lifestyle interventions effectively prevent T2D development [9-12]. However, hereditary factors have also been identified as important modulators of individual susceptibility for T2D development and response to lifestyle interventions [13-15]. These facts support the demand for further research on the molecular bases of DM and elucidating new factors involved in DM pathogenesis.

The past decades brought high attention to microRNAs (miRNAs) as new fine regulators of gene expression, miRNAs are small ( 22-nucleotide long) non-coding one-stranded RNAs harboring a "seed" sequence at 5'-end, which is usually 6-8 nucleotides long and 
binds the $3^{\prime}$ untranslated region ( $3^{\prime} \mathrm{UTR}$ ) of specific target messenger RNA (mRNA). Upon binding to the mRNA $3^{\prime}$ UTR, miRNAs either block translation from this mRNA or facilitate its degradation, thereby repressing gene expression [16-19].

Thousands of mammalian mRNAs have been predicted to be targeted by miRNAs and hundreds of such interactions have been experimentally proven so far [20,21]. An overwhelming amount of data demonstrated that miRNAs fine-tuning of gene expression plays indispensable roles in human development and disease [22-29].

\section{2. miR-155 Biogenesis}

First discovered in chicken in 1997, miR-155 was identified as a product of a gene that was transcriptionally activated by promoter insertion at a common retroviral integration site in B-cell lymphomas and was formerly called B-cell Integration Cluster (BIC) [30]. Its homologs were later identified in humans and mice [31,32]. The maturation of miR155 follows the conventional process of miRNA biogenesis (summarized in Figure 1), which starts with pri-miRNA transcription and is followed by its cleavage by the nuclear microprocessor complex (including Drosha and DGCR8 proteins) with a production of a 65-nucleotide stem-loop precursor miRNA (pre-miR-155). After being exported from the nucleus by exportin-5, pre-miR-155 molecules are cleaved again by Dicer, resulting in RNA duplexes of $\sim 22$ nucleotides. Argonaute protein binds to the short RNA duplexes, forming the core of a multi-subunit complex called RNA-induced silencing complex (RISC), generating one-stranded RNA molecules capable of mRNA binding [33,34].

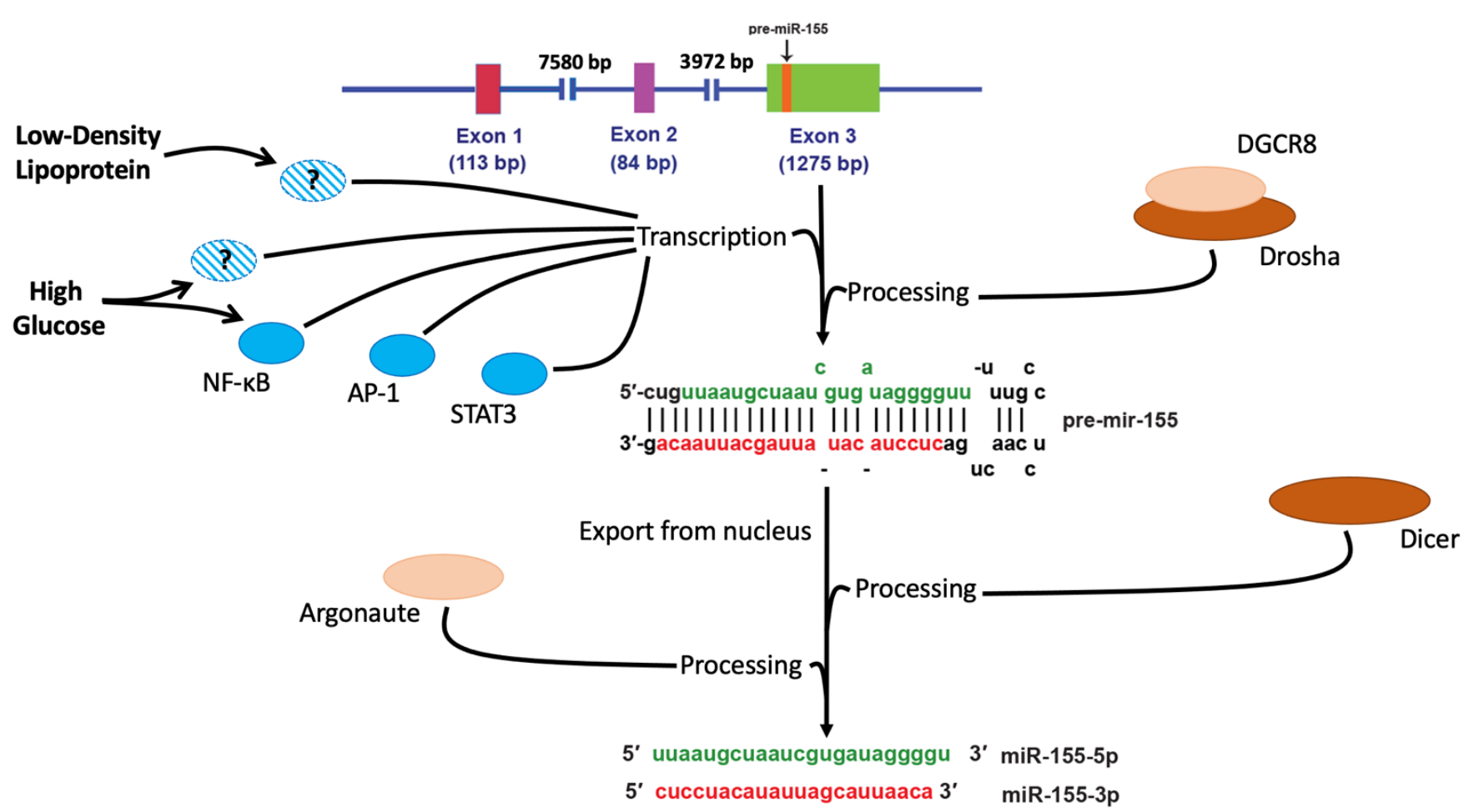

Figure 1. Schematic overview of miR-155 biogenesis. Several transcription factors (including NF- $\mathrm{B}$, AP-1, and STAT3) have been identified as positive regulators of miR-155. High-glucose and LDL also upregulate miR-155 transcription, however, the exact signaling pathways are not fully understood. The transcript is cleaved by the nuclear microprocessor complex (including Drosha and DGCR8 proteins) with a production of a 65-nucleotide stem-loop precursor miRNA (premiR-155); pre-miR-155 is exported from the nucleus by exportin-5 and cleaved by Dicer resulting in RNA duplexes of $\sim 22$ nucleotides. Argonaute binds to the miR-155 duplexes, forming the core of RISC complex, producing one-stranded RNA molecules. Both arms of the pre-miRNA hairpin, denoted as miR-155-5p and miR-155-3p, can give rise to mature miRNAs possessing biological activity. 
Both arms of the pre-miRNA hairpin can give rise to mature miRNAs possessing the biological activity [35-37]. They are denoted with the suffix $-5 p$ (from the $5^{\prime}$ arm) (e.g., miR-155-5p) and $-3 p$ (from the $3^{\prime}$ arm) (e.g., miR-155-3p) [38].

\section{Dysregulation of miR-155 in DM: Findings from Clinical Studies}

The main clinical studies investigating miR-155 and DM are reported in Table 1. A significant decrease in serum levels of miR-155 in T2D patients has been shown in Italian, Chinese, Egyptian, Brazilian, and Iranian cohorts, exposing a striking consistence among the different ethnic backgrounds [39-43].

Table 1. List of clinical studies examining the association between miR-155 dysregulation and T1D or T2D and their complications. The studies investigating circulating levels of miR-155 are positioned at the top of the table, whereas the studies investigating tissue levels of miR-155 are at the bottom of the table. $\uparrow:$ upregulation, $\downarrow$ : downregulation.

\begin{tabular}{|c|c|c|c|c|}
\hline Groups Compared & $\mathbf{N}$ & Tissue(s) & Main Findings & Ref. \\
\hline $\begin{array}{l}\text { T2D patients with or without } \\
\text { diabetic retinopathy and } \\
\text { healthy controls }\end{array}$ & 170 & plasma & $\begin{array}{l}\uparrow \mathrm{miR}-155 \text { in T2D patients with diabetic } \\
\text { retinopathy compared to both controls and } \\
\text { T2D patients without retinopathy }\end{array}$ & [44] \\
\hline $\begin{array}{l}\text { T1D and age-matched } \\
\text { healthy controls }\end{array}$ & 59 & plasma & $\begin{array}{l}\uparrow \mathrm{miR}-155 \text { in T1D patients } \\
\text { compared to controls }\end{array}$ & [45] \\
\hline $\begin{array}{l}\text { T2D patients with or without } \\
\text { diabetic nephropathy }\end{array}$ & 145 & serum & $\begin{array}{c}\uparrow \mathrm{miR}-155 \text { in patients with diabetic } \\
\text { nephropathy compared to T2D patients } \\
\text { without diabetic nephropathy } \\
\text { miR-155 corelated with microalbuminuria }\end{array}$ & [46] \\
\hline $\begin{array}{c}\text { Patients with diabetic } \\
\text { nephropathy and } \\
\text { healthy controls }\end{array}$ & 38 & serum & $\begin{array}{l}\uparrow \mathrm{miR}-155 \text { in patients with diabetic } \\
\text { nephropathy compared to healthy controls }\end{array}$ & [47] \\
\hline $\begin{array}{c}\text { Patients with chronic hepatitis C } \\
\text { with or without T2D, } \\
\text { patients with T2D alone and } \\
\text { healthy controls }\end{array}$ & 80 & serum & $\begin{array}{l}\downarrow \text { miR-155 in T2D patients compared to } \\
\text { healthy controls } \\
\downarrow \text { miR-155 in patients with } \\
\text { chronic hepatitis C virus infection and } \\
\text { T2D compared to patients with chronic } \\
\text { hepatitis } C \text { virus infection alone }\end{array}$ & [41] \\
\hline $\begin{array}{c}\text { T2D patients (grouped } \\
\text { according to the level of } \\
\text { albuminuria) and age-matched } \\
\text { healthy controls }\end{array}$ & 83 & serum & $\begin{array}{l}\downarrow \text { miR-155 in T2D patients } \\
\text { regardless of albumin excretion } \\
\text { compared to healthy controls }\end{array}$ & [42] \\
\hline $\begin{array}{l}\text { T2D and age-matched } \\
\text { healthy controls }\end{array}$ & 60 & serum & $\begin{array}{l}\downarrow \text { miR-155 in T2D patients } \\
\text { compared to controls }\end{array}$ & [40] \\
\hline $\begin{array}{l}\text { T2D patients without diabetic } \\
\text { retinopathy, with } \\
\text { non-proliferative retinopathy or } \\
\text { proliferative retinopathy and } \\
\text { healthy controls }\end{array}$ & 80 & $\begin{array}{l}\text { serum } \\
\text { peripheral white } \\
\text { blood cells }\end{array}$ & $\begin{array}{l}\downarrow \text { miR-155 in T2D patients compared to } \\
\text { healthy controls } \\
\quad \downarrow \text { miR-155 in T2D patients with } \\
\text { non-proliferative retinopathy compared to } \\
\text { T2D patients without retinopathy } \\
\downarrow \text { miR-155 in T2D patients with proliferative } \\
\text { retinopathy compared to T2D patients with } \\
\text { non-proliferative retinopathy }\end{array}$ & [43] \\
\hline $\begin{array}{l}\text { T2D and age-matched } \\
\text { healthy controls }\end{array}$ & 40 & $\begin{array}{l}\text { peripheral blood } \\
\text { mononuclear cells }\end{array}$ & $\begin{array}{l}\downarrow \text { miR-155 in T2D patients } \\
\text { compared to controls }\end{array}$ & [48] \\
\hline $\begin{array}{l}\text { T2D and age-matched } \\
\text { healthy controls }\end{array}$ & 40 & $\begin{array}{l}\text { peripheral blood } \\
\text { mononuclear cells }\end{array}$ & $\begin{array}{l}\downarrow \text { miR-155 in T2D patients } \\
\text { compared to controls }\end{array}$ & [49] \\
\hline $\begin{array}{l}\text { T1D patients and } \\
\text { healthy controls }\end{array}$ & 959 & $\begin{array}{l}\text { peripheral white } \\
\text { blood cells }\end{array}$ & $\begin{array}{l}\text { miR-155 rs767649 polymorphisms } \\
\text { associated with protection from T1D }\end{array}$ & [50] \\
\hline $\begin{array}{l}\text { T1D and age-matched } \\
\text { healthy controls }\end{array}$ & 86 & $\begin{array}{l}\text { peripheral blood } \\
\text { mononuclear cells }\end{array}$ & $\begin{array}{l}\uparrow \mathrm{miR}-155 \text { in T1D patients } \\
\text { compared to controls }\end{array}$ & [51] \\
\hline $\begin{array}{l}\text { T1D and age-matched } \\
\text { healthy controls }\end{array}$ & 41 & $\begin{array}{l}\text { peripheral blood } \\
\text { mononuclear cells }\end{array}$ & $\begin{array}{l}\uparrow \text { miR-155 in T1D patients } \\
\text { compared to controls }\end{array}$ & [52] \\
\hline
\end{tabular}


Table 1. Cont.

\begin{tabular}{|c|c|c|c|c|}
\hline Groups Compared & $\mathbf{N}$ & Tissue(s) & Main Findings & Ref. \\
\hline $\begin{array}{l}\text { T2D patients with or without } \\
\text { diabetic neuropathy, } \\
\text { healthy controls }\end{array}$ & 64 & $\begin{array}{l}\text { peripheral blood } \\
\text { mononuclear cells }\end{array}$ & $\begin{array}{l}\downarrow \mathrm{miR}-155 \text { in T2D patients with diabetic } \\
\text { neuropathy compared to both } \\
\text { healthy controls and T2D patients } \\
\text { without diabetic neuropathy }\end{array}$ & [39] \\
\hline $\begin{array}{l}\text { T2D patients without diabetic } \\
\text { retinopathy, with } \\
\text { non-proliferative retinopathy or } \\
\text { proliferative retinopathy and } \\
\text { healthy controls }\end{array}$ & 80 & $\begin{array}{l}\text { peripheral blood } \\
\text { mononuclear cells }\end{array}$ & $\begin{array}{l}\uparrow \mathrm{miR}-155 \text { in T2D patients } \\
\text { compared to healthy controls } \\
\uparrow \mathrm{miR}-155 \text { in T2D patients with } \\
\text { non-proliferative retinopathy compared to } \\
\text { T2D patients without retinopathy } \\
\uparrow \mathrm{miR}-155 \text { in T2D patients with proliferative } \\
\text { retinopathy compared to T2D patients with } \\
\text { non-proliferative retinopathy }\end{array}$ & [53] \\
\hline $\begin{array}{c}\text { Pregnant women with } \\
\text { gestational diabetes and healthy } \\
\text { pregnant women }\end{array}$ & 69 & $\begin{array}{l}\text { peripheral white } \\
\text { blood cells }\end{array}$ & $\begin{array}{l}\downarrow \text { miR-155 in pregnant women with } \\
\text { gestational diabetes } \\
\text { compared to healthy controls }\end{array}$ & [54] \\
\hline $\begin{array}{l}\text { T2D and age-matched } \\
\text { healthy controls }\end{array}$ & 44 & platelets & $\begin{array}{l}\downarrow \text { miR-155 in T2D patients } \\
\text { compared to controls }\end{array}$ & [55] \\
\hline $\begin{array}{l}\text { T1D patients with or without } \\
\text { diabetic retinopathy and } \\
\text { healthy controls }\end{array}$ & 21 & $\begin{array}{c}\text { extracellular } \\
\text { vesicles from blood }\end{array}$ & $\begin{array}{l}\downarrow \mathrm{miR}-155 \text { in T1D patients with diabetic } \\
\text { retinopathy compared to both } \\
\text { healthy controls and T1D patients } \\
\text { without diabetic retinopathy }\end{array}$ & [56] \\
\hline $\begin{array}{l}\text { T2D patients and age-matched } \\
\text { healthy controls }\end{array}$ & 15 & adipose tissue & $\begin{array}{l}\text { miR-155 inversely correlated with mean } \\
\text { adipocyte volume and } \\
\text { macrophage infiltration }\end{array}$ & [57] \\
\hline Obese and non-obese patients & 50 & adipose tissue & $\uparrow \mathrm{miR}-155$ in obese individuals & [58] \\
\hline $\begin{array}{c}\text { Patients with diabetic } \\
\text { nephropathy and } \\
\text { healthy controls }\end{array}$ & 9 & kidney & $\begin{array}{l}\uparrow \mathrm{miR}-155 \text { in patients with diabetic } \\
\text { nephropathy compared to healthy controls }\end{array}$ & [59] \\
\hline $\begin{array}{l}\text { Patients with diabetic } \\
\text { nephropathy and } \\
\text { healthy controls }\end{array}$ & 98 & kidney & $\begin{array}{l}\uparrow \mathrm{miR}-155 \text { in patients with diabetic } \\
\text { nephropathy compared to healthy controls }\end{array}$ & [60] \\
\hline $\begin{array}{l}\text { T1D patients with or without } \\
\text { diabetic nephropathy and } \\
\text { healthy controls }\end{array}$ & 192 & $\begin{array}{l}\text { urine } \\
\text { kidney }\end{array}$ & $\begin{array}{c}\uparrow \mathrm{miR}-155 \text { in patients with diabetic } \\
\text { nephropathy compared to healthy controls } \\
\text { and T1D patients without } \\
\text { diabetic nephropathy }\end{array}$ & [61] \\
\hline $\begin{array}{l}\text { T1D patients with or without } \\
\text { albuminuria and } \\
\text { healthy controls }\end{array}$ & 34 & urinary exosomes & $\begin{array}{c}\downarrow \text { miR-155 in T1D patients with albuminuria } \\
\text { compared both to T1D patients } \\
\text { without albuminuria and healthy control }\end{array}$ & [62] \\
\hline
\end{tabular}

A reduced expression of miR-155 was observed in peripheral blood mononuclear cells (PBMCs) isolated from T2D patients compared to healthy volunteers [48,49]. Similarly, a decreased miR-155 expression was reported in platelets of diabetic patients [55]. Low plasma levels of miR-155 were also found in gestational DM [54]. Interestingly, patients with hepatitis $C$ and insulin resistance also displayed lower serum levels of miR-155 compared to those with hepatitis $C$ without insulin resistance, although hepatitis $C$ infection was associated with manifold upregulation of this miRNA [41]. Plasma levels of miR-155-5p were shown to correlate with diabetic neuropathy: patients with diabetic distal symmetric sensorimotor polyneuropathy and diabetic cardiovascular autonomic neuropathy had lower plasma levels of miR-155 compared to DM patients without neurological symptoms [39]. Corral-Fernández et al. showed that the downregulation of miR-155 in PBMCs was more pronounced in patients with exaggerated obesity [48].

The expression of IL- 6 and TNF $\alpha$ in response to LPS was found to be augmented in PBMCs isolated from T2D patients compared to cells obtained from healthy controls [49], providing a possible mechanistic link to higher plasma levels of IL-6 in T2D [48]. Of note, miR-155 expression was also found to be altered in the adipose tissue [58]. 
Profiling miRNAs expression in omental and subcutaneous adipose tissue revealed that miR-155 expression had a negative correlation with the mean adipocyte volume in omental fat and with macrophage infiltration in subcutaneous adipose tissue [57]. Obese non-diabetic patients displayed increased levels of miR-155 both in bloodstream and in adipose tissue, suggesting that miR-155 upregulation may play a beneficial role in maintaining adipose tissue health [58].

Surprisingly, despite the abundant data showing downregulation of miR-155 in T2D, patients suffering from T1D displayed an increased expression of miR-155 in PBMCs compared to healthy subjects [51,52]. T1D patients also had a higher prevalence of the T/T allele for the rs767649 polymorphism of miR-155, which is likely associated with a higher transcriptional activity of miR-155 [50]. Assamann and collaborators have demonstrated that miR-155-5p serum levels are robustly upregulated in freshly diagnosed T1D patients, whereas more than 5 years of disease are associated with its downregulation [45].

In contrast to other tissues, renal expression of miR-155 seems to be augmented in DM. An elegant study by Baker et al. utilized laser microdissection to evaluate the changes in miRNAs expression in the kidney, showing that diabetic nephropathy is associated with increased miR-155 expression in proximal tubules, but not in glomeruli [60]. A study made on a smaller number of patients revealed a higher expression of miR-155-5p both in renal tubules and glomeruli in patients with diabetic nephropathy compared to healthy individuals [59]. High serum levels of miR-155 were found in patients with diabetic nephropathy in two trials [46,47]. Moreover, when combined with high urinary levels of vitamin D binding protein, elevated serum miR-155 appeared to be a strong predictor of rapid disease progression [46]; these findings were accompanied by the observation of a robust increase in urinary levels of miR-155 [61].

Nevertheless, a study measuring miR-155 in urinary exosomes demonstrated that patients with DM had lower amounts of miR-155 than healthy volunteers [62]. Similarly, miR-155 levels in urinary exosomes were lower in diabetic patients with microalbuminuria than in diabetic patients with unaltered renal function [62]. Difficulties in precisely trace the origin of urinary exosomes, which could be shed from epithelial cells all along the nephron and urinary tract, may explain the contradiction between this study and other results on renal expression of miR-155.

Controversial results were reported when exploring the correlation between miR-155 levels and diabetic retinopathy. On the one hand, a clinical study revealed decreased levels of miR-155 in patients with diabetic retinopathy compared to diabetic patients with no eye abnormalities [56]. Another study identified the A-allele of rs767649 polymorphism in miR-155 gene as a strong predictor of diabetic retinopathy [43]. The A-allele of rs767649 polymorphism is associated with lower transcriptional activity of miR-155. However, plasma levels of miR-155 demonstrated no predictive power in this study $[43,50]$.

On the other hand, a study in Chinese patients revealed a positive correlation between the severity of diabetic retinopathy and plasma levels of miR-155 [53], and a large cohort of Brazilian patients showed no association between high plasma levels of miR-155-3p and diabetic retinopathy [44].

\section{Different Roles of miR-155 in the Pathogenesis of T1D and T2D}

\section{1. $m i R-155$ and $T 2 D$}

Pancreatic $\beta$-cell dysfunction and insulin resistance are two hallmarks of T2D [8,63-68]. Epidemiologic studies suggest that more than $60 \%$ of T2D can be attributed to obesity [69]. However, the effects of high body adiposity on $\beta$-cell function remain not fully understood [70]. The examination of human pancreatic tissue received from patients with a different disease status revealed a bell-shaped curve relationship between $\beta$-cell mass and disease progression.

At least in the initial phases of the disease, obese non-diabetic patients exhibit a $25-50 \%$ increase in $\beta$-cell mass and indirect evidence suggests an increased capacity of $\beta$ cells to release insulin [71-77], most likely as adaption to increased glucose uptake [77-83]. 
However, after the onset of frank hyperglycemia, $\beta$-cell mass starts to fall down, eventually reaching levels even lower than those of healthy lean individuals $[79,81,82,84,85]$. The insulin secretion capacity of $\beta$-cells from patients with overt T2D is also impaired, thereby further compromising insulin levels [86-91].

Preclinical studies suggest that the decreased expression of miR-155 observed in T2D patients may represent one of the mechanisms underlying the declined pancreatic function. Indeed, miR-155 whole-body knockout or overexpression in mice did not significantly affect islet number and morphology, insulin expression, or $\beta$-cell proliferation [40]. However, miR-155 deficiency markedly decreased $\beta$-cell expansion in response to hypercholesteremia and was also accompanied by diminished insulin secretion and augmented expression of glucagon, alongside a relative increase of glucagon positive cells in pancreatic islets, thus recapitulating the pathological findings of human T2D [92]. The same group of researchers found that miR-155 expression was directly upregulated in $\beta$-cells by both native and myeloperoxidase-modified low-density lipoproteins [92]. The main target of miR-155 appeared to be V-maf musculoaponeurotic fibrosarcoma oncogene homolog B (MafB), an established master regulator of the $\alpha$-cell phenotype [92].

Another preclinical study demonstrated that upon high-fat diet a phenotype switch occurs in the islets of Langerhans, with insulin-producing $\beta$-cells re-differentiating into glucagon-producing $\alpha$-cells [93]. Thus, miR-155 is a pivotal factor maintaining $\beta$-cell fitness; its upregulation represents a $\beta$-cell adaptation to overnutrition and disruption of this mechanism may be a key event in the transition from prediabetes to T2D.

A fundamental feature of T2D is insulin resistance, a condition of blunted response to insulin of tissues, mainly skeletal muscles, fat, and liver [8,94]. Skeletal muscles and adipose tissue respond to insulin by enhancing glucose uptake and thus playing a central role in the regulation of glucose homeostasis.

The liver is the main body site of endogenous glucose synthesis $[95,96]$ and this process is inhibited by insulin [97,98]. Mice lacking miR-155 fed normal chow exhibit impaired glucose tolerance and decreased insulin sensitivity with unaltered insulin production capacity. Instead, global miR-155 overexpression ameliorates both glucose tolerance and insulin sensitivity [40]. This effect is mainly achieved through means of the downregulation of genes involved in negative modulation of insulin receptor signaling and upregulation of glucose uptake genes in adipose tissue and skeletal muscle. In the liver, miR-155 downregulates both negative modulators of insulin receptor signaling and genes involved in gluconeogenesis [40]. Indeed, miR-155 directly targets the $3^{\prime} \mathrm{UTRs}$ of CCAAT-enhancerbinding protein $\beta(C / E B P \beta)$ and Histone deacetylase 4 (HDAC4).

Thus, a decreased expression of miR-155 in T2D patients may be one of the fundamental factors underlying the development of insulin resistance (Figure 2).

\section{2. $\mathrm{miR}-155$ and $T 1 D$}

In contrast to T2D, the primary mechanism of T1D is an autoimmune attack on $\beta$-cells, and the progressive loss of insulin producing cells underlies the disease progression. Both human and animal data have shown that the functional contribution of miR-155 in the pathogenesis of T1D could be totally different from what was observed in T2D. Results obtained in a murine model of T1D—non-obese diabetic (NOD) mice-appeared to be consistent with findings in clinical studies and demonstrated an upregulation of miR155 [99]. This animal model also recapitulated the increased expression of miR-155 in some types of immune cells [51,52,99].

Moreover, miR-155 was markedly enriched in exosomes derived from T-lymphocytes of NOD mice. $\beta$-cells treated with these exosomes underwent apoptosis and such effect was inhibited by inhibiting miR-155. Similarly, the ectopic expression of a specific long non-coding RNA (LcnRNA) sponging miR-155 mitigated the development of DM in NOD mice [99]. These data strongly suggest that the upregulation of miR-155 in immune cells contributes to $\beta$-cell death in T1D. 


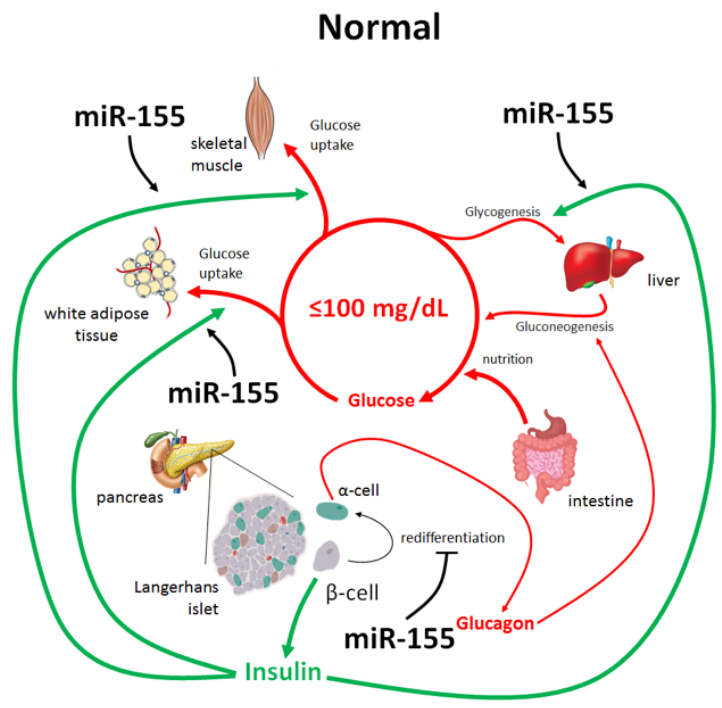

T1D

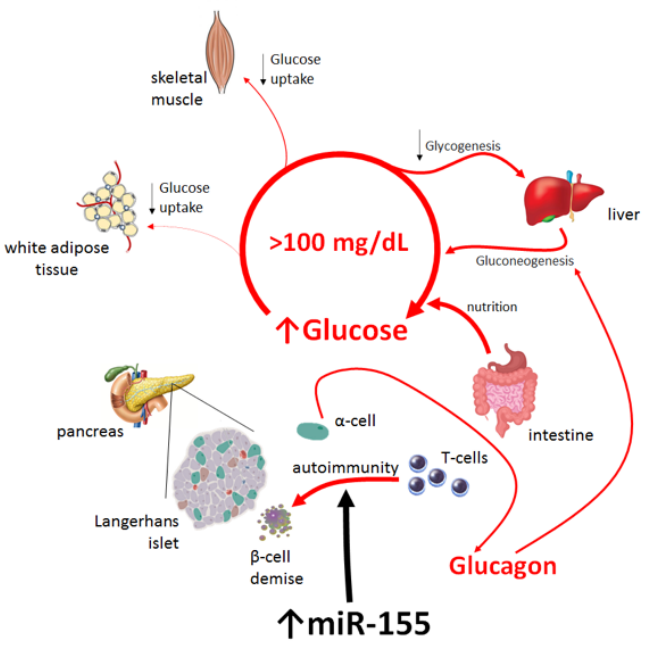

T2D

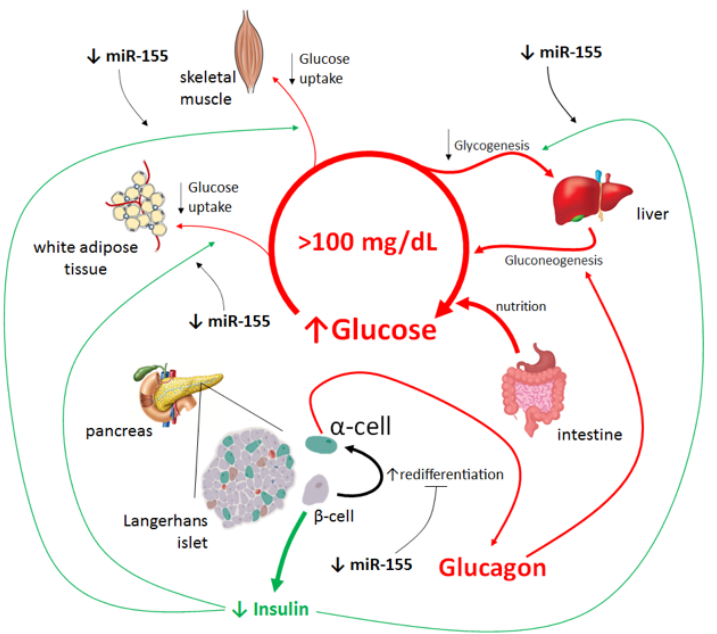

Figure 2. Functional roles of miR-155 in glucose homeostasis. The cartoon emphasizes the involvement of miR-155 in the key mechanisms underlying glucose homeostasis: in normal conditions, in type 1 diabetes (T1D) and in type 2 diabetes (T2D); miR-155 improves insulin sensitivity and glucose uptake in white adipose tissue and skeletal muscle and promotes gluconeogenesis in the liver. Moreover, miR-155 prevents the trans-differentiation of $\beta$-cells into $\alpha$-cells under metabolic stress.

Activating mutations in the Signal transducer and activator of transcription 3 (STAT3) have been proposed to cause T1D, most likely via impaired development of regulatory $\mathrm{T}$ cells (Tregs) and expansion and activation of T helper type 17 cells [100-104]. Interestingly, STAT3 is able to bind and upregulate the expression of the miR-155 promoter [105].

Furthermore, STAT3 dependent upregulation of miR-155 has been shown to play a crucial role in the development of several autoimmune pathologies, giving another clue to the potential deleterious role of miR-155 in the pathogenesis of T1D [106-108].

Another protein involved in the pathophysiology of T1D is Forkhead box protein P3 (FOXP3). Mutations in its gene are known to cause T1D [109], most likely since the FOXP3 activity is required for Tregs maturation, which in turn suppresses the cytolytic activity of $\mathrm{CD}^{+}$and $\mathrm{CD} 8^{+} \mathrm{T}$ cell [110]. Mice specifically overexpressing miR-155 in FOX3P3 ${ }^{+}$ Tregs exhibit spontaneous autoimmunity [111], whereas miR-155 deficiency results in the disproportional loss of Tregs and inability to maintain immune homeostasis [112-114]. 


\section{Physiological Roles of miR-155}

Several studies have shown that miR-155 plays important roles in hematopoiesis. It was identified among five other miRNAs (i.e., miR-142, miR-144, miR-150, miR-155, and miR-223) that were specific for hematopoietic cells both in humans and in mice [35].

Further experiments demonstrated that miR-155 is highly expressed in hematopoietic stem-progenitor cells (HSPCs) and maintains cells in an undifferentiated state via direct repression of transcription factor PU.1 [115-117]. Forced overexpression of miR-155 markedly reduced both myeloid and erythroid colony formation of normal human HSPCs [115].

miR-155 may also play independent roles in the regulation of erythropoiesis, since its expression is drastically decreased upon differentiation of human erythroid progenitors into erythroblasts [118].

Additionally, miR-155 plays vital actions in immune cells, being essential for the differentiation of Tregs by repressing the expression of Suppressor of cytokine signaling 1 (SOCS1) [112,119]. miR-155 is also involved in the selection of competent B cells in germinal centers, since its deficiency has been shown to allow immature B cells to avoid apoptosis $[116,120,121]$, and in innate immune response, playing a pro-inflammatory role: Its expression is dramatically upregulated in macrophages, dendritic cells, and other immune cells upon Toll-like receptors (TLRs) activation by pathogen associated molecular patterns [122-126].

Nuclear factor kappa-light-chain-enhancer of activated B cells (NF- $\mathrm{kB}$ ) and Activator protein 1 (AP-1) were identified as two main transcription factors responsible for miR155 transcriptional activity $[122,123,127,128]$; miR-155-5p suppresses negative regulators of inflammation, such as inositol polyphosphate-5-phosphatase (INPP5D, also known as SHIP1) and SOCS1, thus promoting immune cell survival, growth, migration, and anti-pathogen responses [128-130].

Nonetheless, some data indicate that miR-155-5p may also limit inflammatory response, suggesting that the role of miR-155 could change according to the different phases of inflammation [131]. Taking in consideration the profound effects of miR-155 on the immune system, it is not surprising that miR-155 was found to be an important factor determining the development and course of cancers, infectious diseases, and autoimmune disorders (including T1D) [132-138].

\section{Functional Role of miR-155 in DM Complications}

Several studies have demonstrated that miR-155 participates in the pathogenesis of diabetic complications, which include nephropathy, neuropathy, cardiomyopathy, and retinopathy [139-145].

\section{1. miR-155 and Pathogenesis of Diabetic Nephropathy}

A primary mechanism of renal damage in DM is uncontrolled hyperglycemia, which triggers glomerular endothelium activation and podocyte dysfunction $[146,147]$. The inflammatory response triggers activation of mesangial cells in the glomeruli, which start to proliferate and produce excessive extracellular matrix substituting capillaries and podocytes, thus resulting in a decline in the glomerular filtration rate. Eventually, glomerulosclerosis triggers tubular epithelium damage with irreversible fibrotic changes [145,148-150].

The expression of miR-155-5p was found to be increased by hyperglycemia both in vitro and in vivo, thus phenocopying the human findings of elevated renal miR-155 expression in diabetic nephropathy [47,151-153]. In animal studies, miR-155-5p overexpression was associated with higher interstitial fibrosis-hallmark of irreversible kidney damage — and attenuated by miR-155-5p inhibition [152,154,155].

Several signaling pathways have been implicated in the beneficial effect of miR-155 inhibition. The first one is the direct binding to the 3'UTRs of Socs1 and Socs6 [154], which are known to inhibit the JAK-STAT pathway, which is also involved in signaling mediated by the master regulator of renal fibrosis, transforming growth factor $\beta 1$ (TGF- $\beta 1$ ) [156,157]. Another confirmed target of miR-155-5p is NAD-dependent deacetylase sirtuin-1 (Sirt1). 
Downregulation of Sirt1 expression by miR-155-5p is followed by suppressed autophagy, as SIRT1 dependent deacetylation is required for the activation of a number of proteins involved in autophagy signaling and execution $[151,155,158,159]$. The third pathway is given by the direct inhibition of Pten, a negative regulator of PI3K/AKT/mTOR pathway, which in turn inhibits autophagy [152]. Consistent with these findings, a number of investigations demonstrated that an impaired autophagic response undermines the kidney ability to cope with pathological stresses [160].

miR-155 may also play a role in the early stages of diabetic nephropathy. Several studies have shown that miR-155 expression is dramatically upregulated in both human and rat glomerular mesangial cells (GMCs) exposed to high-glucose [47,153]. Interestingly, miR-155 upregulation is blunted in TLR4-deficient cells, suggesting a primary role of inflammation in miR-155 transcriptional control [153]. This view is supported by the augmented miR-155 expression observed in human GMCs in response to pro-inflammatory cytokines [161]. Moreover, treatment with LncRNA CTBP1-AS2 sponging miR-155 protects GMCs by diminishing miR-155-mediated repression of Foxo1 [47]; miR-155 inhibition was also able to reduce TGF- $\beta 1$-induced signaling in podocytes in vitro, and a decreased expression of markers of podocyte injury was observed under miR-155 inhibition in vivo [162,163].

\subsection{Role of miR-155 in the Pathogenesis of Diabetic Neuropathy and Diabetic Cardiomyopathy}

Preclinical studies investigating the potential role that miR-155 could play in diabetic neuropathy have emphasized the differences between T1D and T2D. Downregulation of miR-155 was found in the sciatic nerve of $d b / d b$ mice, an established model of T2D (119). The treatment with miR-155 mimic had profound beneficial effects characterized by augmented velocities of conduction in both sensory and motor nerves and significant decrease in the threshold to thermal stimuli; miR-155 also reversed the DM-triggered production of inflammatory cytokines and the upregulation of neurogenic locus notch homolog protein 2 (Notch2) (119).

Instead, a study utilizing a model of T1D revealed that miR-155 inhibition protected animals from nerve demyelination. This effect was attributed to the direct downregulation of nuclear factor erythroid 2-related factor 2 ( $N r f 2$ ) expression by miR-155 and subsequent apoptosis of Schwann cells exposed to high-glucose (120).

in vitro assays have demonstrated that hyperglycemia upregulates miR-155 expression in cardiomyoblasts, leading to an increased expression of pro-fibrotic genes and development of mitochondrial dysfunction [164]. Of note, a tight glycemic control tested in vivo in a model of T1D failed to prevent miR-155 upregulation in the heart [165].

\section{3. miR-155 and Diabetic Retinopathy}

Diabetic eye disease affects approximately $80 \%$ of patients who have been affected by T1D or T2D for at least 20 years [166]. The disease starts with non-proliferative lesions such as altered retinal blood flow and vascular permeability, basement membrane thickening, loss of pericytes, and the formation of acellular capillaries, causing macular edema. Then, the disease enters into a proliferative stage, associated with pathological neovascularization: vessels grow into the vitreous eliciting hemorrhagic events or retinal detachment which may result into blindness $[167,168]$.

An upregulation of miR-155 was also observed in several animal models of retinal injury $[169,170]$. The global ablation of miR-155 in mice did not produce significant changes to retinal architecture or retinal angiogenesis [169,170]. Nonetheless, miR-155 expression was upregulated in human retinal microvascular endothelial cells (HRMECs) upon treatment with vascular endothelial growth factor (VEGF) in vitro and inhibition of miR-155 abrogated VEGF-mediated proliferation, migration, and ability to form networklike structures of HRMECs [171].

Both the knockout of miR-155 and its inhibition were shown to prevent the pathological neovascularization of the retina and to attenuate vision loss [169-171]. Additionally, miR-155 affected endothelial function via downregulation of Ship1, a negative regulator 
of PI3K/AKT pathway, and Cysteine-rich angiogenic inducer 61 (Cyr61, also known as Con1), an extracellular matrix-associated integrin-binding protein that promotes angiogenesis [170-174].

Upregulation of miR-155 was also reported in human retinal pigment epithelium treated with pro-inflammatory cytokines [175]. Another indication of the deleterious role of high miR-155 in retinopathies came from a study showing that saponin-mediated protection of photoreceptors involves precluding miR-155 overexpression in macrophages [176].

\section{Conclusions and Perspectives}

Taken together, the data discussed above provide a strong evidence in support of miR155 as a new key player in the pathogenesis of DM. Numerous clinical studies performed in different centers show that miR-155 downregulation is a common finding in T2D patients. Of course, large multicenter trials are required to determine if circulating levels of miR-155 could be established as a new and reliable biomarker of T2D. Considering that animal studies revealed miR-155 downregulation as a potential trigger of insulin resistance and $\beta$-cells loss, miR-155 may possibly be used for early diagnostics of T2D or prediction of T2D outcomes.

miR-155 may also represent a new drug target. The success of COVID-19 vaccines BNT162b2 and mRNA-1273, based on mRNA delivery, could also open the possibility to use miRNA-based approaches as a medication to tackle DM [177-179]. Another important direction in miR-155 research is to determine the mechanisms underlying its downregulation in T2D, which should likely provide other more conventional targets for drug development.

The net effect of miR-155 downregulation or overexpression could be dissimilar in different organs. However, the experimental data from human studies provides us with a clear pattern showing that miR-155 tends to be decreased in patients with T2D and increased in T1D. Such a discrepancy could be related to the different pathogenesis of these two diseases. The findings in animal models are consistent with clinical trials and may provide the basis for potential mechanistic explanations. We speculate that miR-155 downregulation contributes to the development of insulin resistance in adipose tissue and skeletal muscle and compromises pancreatic insulin secretion by dedifferentiating $\beta$-cells. Furthermore, mounting evidence indicates that high levels of miR-155 favor progression of a number of autoimmune pathologies, including insulitis.

A relatively small amount of data is available on the role of miR-155 in T1D. Studies performed hitherto strongly suggest that miR-155 plays detrimental roles in autoimmune demise of $\beta$-cells. Nevertheless, more studies are required to establish an unambiguous association linking miR-155 and T1D. If confirmed, miR-155 may become a screening tool for detecting insulitis before frank clinical manifestations. Moreover, if miR-155 is in fact involved in autoimmune destruction of $\beta$-cells, it might be harnessed as a target for T1D treatment. Of note, drugs based on miR-155 inhibition are already under extensive development [180].

Inhibition of miR-155 may also become a therapeutic option for DM complications. Human and animal data consistently point to the essential role of miR-155 upregulation in diabetic nephropathy. Promising results have been obtained in preclinical models of diabetic neuropathy giving hope for mitigation of neuropathic pain and peripheral demyelination. Experimental models of diabetic retinopathy also hint that miR-155 inhibition may save vision for millions of DM patients. However, clinical data on diabetic retinopathy remain controversial and require further investigation.

Author Contributions: S.S.J. wrote the first draft; J.G., C.S., A.L. and G.S. edited the manuscript. All authors have read and agreed to the published version of the manuscript.

Funding: The Santulli's Lab is supported in part by the National Institutes of Health (NIH: R01DK123259, R01-HL146691, R01-DK033823, R01-HL159062, R56-AG066431, T32-HL144456, and R00DK107895, to G.S.), by the Irma T. Hirschl and Monique Weill-Caulier Trusts (to G.S.) and by the American Heart Association (AHA-21POST836407 to S.S.J. and AHA-20POST35211151 to J.G.). 
Conflicts of Interest: The authors declare no conflict of interest.

\section{References}

1. American Diabetes Association ADA 2. Classification and diagnosis of diabetes: Standards of medical care in diabetes-2020. Diabetes Care 2020, 43, S14-S31. [CrossRef] [PubMed]

2. Carracher, A.M.; Marathe, P.H.; Close, K.L. International Diabetes Federation 2017. J. Diabetes 2018, 10, 353-356. [CrossRef] [PubMed]

3. GBD 2013 Mortality and Causes of Death Collaborators. Global, regional, and national age-sex specific all-cause and cause-specific mortality for 240 causes of death, 1990-2013: A systematic analysis for the Global Burden of Disease Study 2013. Lancet 2015, 385, 117-171. [CrossRef]

4. Roglic, G.; Unwin, N. Mortality attributable to diabetes: Estimates for the year 2010. Diabetes Res. Clin. Pract. 2010, 87, 15-19. [CrossRef]

5. Saeedi, P.; Salpea, P.; Karuranga, S.; Petersohn, I.; Malanda, B.; Gregg, E.W.; Unwin, N.; Wild, S.H.; Williams, R. Mortality attributable to diabetes in 20-79 years old adults, 2019 estimates: Results from the International Diabetes Federation Diabetes Atlas, 9th edition. Diabetes Res. Clin. Pract. 2020, 162, 108086. [CrossRef]

6. Lombardi, A.; Tsomos, E.; Hammerstad, S.S.; Tomer, Y. Interferon alpha: The key trigger of type 1 diabetes. J. Autoimmun. 2018, 94, 7-15. [CrossRef] [PubMed]

7. Accili, D. Whither Type 1 Diabetes? N. Engl. J. Med. 2020, 383, 2078-2079. [CrossRef]

8. Zheng, Y.; Ley, S.; Hu, F.B. Global aetiology and epidemiology of type 2 diabetes mellitus and its complications. Nat. Rev. Endocrinol. 2018, 14, 88-98. [CrossRef]

9. Knowler, W.C.; Barrett-Connor, E.; Fowler, S.E.; Hamman, R.F.; Lachin, J.M.; Walker, E.A.; Nathan, D.M. Reduction in the Incidence of Type 2 Diabetes with Lifestyle Intervention or Metformin. N. Engl. J. Med. 2002, 346, 393-403. [CrossRef]

10. Mayor, S. International Diabetes Federation consensus on prevention of type 2 diabetes. Int. J. Clin. Pract. 2007, 61, 1773-1775. [CrossRef]

11. Tuomilehto, J.; Lindström, J.; Eriksson, J.G.; Valle, T.T.; Hämäläinen, H.; Ilanne-Parikka, P.; Keinänen-Kiukaanniemi, S.; Laakso, M.; Louheranta, A.; Rastas, M.; et al. Prevention of Type 2 Diabetes Mellitus by Changes in Lifestyle among Subjects with Impaired Glucose Tolerance. N. Engl. J. Med. 2001, 344, 1343-1350. [CrossRef]

12. Pan, X.-R.; Li, G.-W.; Hu, Y.-H.; Wang, J.-X.; Yang, W.-Y.; An, Z.-X.; Hu, Z.-X.; Lin, J.-; Xiao, J.-Z.; Cao, H.-B.; et al. Effects of Diet and Exercise in Preventing NIDDM in People With Impaired Glucose Tolerance: The Da Qing IGT and Diabetes Study. Diabetes Care 1997, 20, 537-544. [CrossRef] [PubMed]

13. Böhm, A.; Weigert, C.; Staiger, H.; Haring, H.-U. Exercise and diabetes: Relevance and causes for response variability. Endocrine 2015, 51, 390-401. [CrossRef]

14. Almgren, P.; Lehtovirta, M.; Isomaa, B.; Sarelin, L.; Taskinen, M.R.; Lyssenko, V.; Tuomi, T.; Groop, L. Heritability and familiality of type 2 diabetes and related quantitative traits in the Botnia Study. Diabetologia 2011, 54, 2811-2819. [CrossRef]

15. Fuchsberger, C.; Flannick, J.; Teslovich, T.M.; Mahajan, A.; Agarwala, V.; Gaulton, K.J.; Ma, C.; Fontanillas, P.; Moutsianas, L.; McCarthy, D.J.; et al. The genetic architecture of type 2 diabetes. Nat. Cell Biol. 2016, 536, 41-47. [CrossRef]

16. Zeng, Y. Principles of micro-RNA production and maturation. Oncogene 2006, 25, 6156-6162. [CrossRef]

17. Valencia-Sanchez, M.A.; Liu, J.; Hannon, G.J.; Parker, R. Control of translation and mRNA degradation by miRNAs and siRNAs. Genes Dev. 2006, 20, 515-524. [CrossRef]

18. Bartel, D.P. MicroRNAs: Target Recognition and Regulatory Functions. Cell 2009, 136, 215-233. [CrossRef] [PubMed]

19. Santulli, G. microRNA: From Molecular Biology to Clinical Practice; Springer Nature: New York, NY, USA, 2016.

20. Lewis, B.P.; Burge, C.B.; Bartel, D.P. Conserved Seed Pairing, Often Flanked by Adenosines, Indicates that Thousands of Human Genes are MicroRNA Targets. Cell 2005, 120, 15-20. [CrossRef]

21. Friedman, R.; Farh, K.K.-H.; Burge, C.B.; Bartel, D.P. Most mammalian mRNAs are conserved targets of microRNAs. Genome Res. 2009, 19, 92-105. [CrossRef] [PubMed]

22. Kloosterman, W.P.; Plasterk, R.H. The diverse functions of microRNAs in animal development and disease. Dev. Cell. 2006, 11, 441-450. [CrossRef] [PubMed]

23. Esteller, M. Non-coding RNAs in human disease. Nat. Rev. Genet. 2011, 12, 861-874. [CrossRef] [PubMed]

24. Zhang, B.; Pan, X.; Cobb, G.; Anderson, T. microRNAs as oncogenes and tumor suppressors. Dev. Biol. 2007, 302, 1-12. [CrossRef] [PubMed]

25. Natarajan, R. Epigenetic Mechanisms in Diabetic Vascular Complications and Metabolic Memory: The 2020 Edwin Bierman Award Lecture. Diabetes 2021, 70, 328-337. [CrossRef]

26. Kiran, S.; Kumar, V.; Kumar, S.; Price, R.; Singh, U. Adipocyte, Immune Cells, and miRNA Crosstalk: A Novel Regulator of Metabolic Dysfunction and Obesity. Cells 2021, 10, 1004. [CrossRef]

27. Chang, W.; Wang, J. Exosomes and Their Noncoding RNA Cargo Are Emerging as New Modulators for Diabetes Mellitus. Cells 2019, 8, 853. [CrossRef]

28. Awazawa, M.; Gabel, P.; Tsaousidou, E.; Nolte, H.; Krüger, M.; Schmitz, J.; Ackermann, P.J.; Brandt, C.; Altmüller, J.; Motameny, S.; et al. A microRNA screen reveals that elevated hepatic ectodysplasin A expression contributes to obesity-induced insulin resistance in skeletal muscle. Nat. Med. 2017, 23, 1466-1473. [CrossRef] 
29. Ying, W.; Riopel, M.; Bandyopadhyay, G.; Dong, Y.; Birmingham, A.; Seo, J.B.; Ofrecio, J.M.; Wollam, J.; Hernandez-Carretero, A.; $\mathrm{Fu}, \mathrm{W}$.; et al. Adipose Tissue Macrophage-Derived Exosomal miRNAs Can Modulate In Vivo and In Vitro Insulin Sensitivity. Cell 2017, 171, 372-384.e12. [CrossRef]

30. Tam, W.; Ben-Yehuda, D.; Hayward, W.S. bic, a novel gene activated by proviral insertions in avian leukosis virus-induced lymphomas, is likely to function through its noncoding RNA. Mol. Cell. Biol. 1997, 17, 1490-1502. [CrossRef]

31. Tam, W. Identification and characterization of human BIC, a gene on chromosome 21 that encodes a noncoding RNA. Gene 2001, 274, 157-167. [CrossRef]

32. Lagos-Quintana, M.; Rauhut, R.; Yalcin, A.; Meyer, J.; Lendeckel, W.; Tuschl, T. Identification of Tissue-Specific MicroRNAs from Mouse. Curr. Biol. 2002, 12, 735-739. [CrossRef]

33. Kim, V.N.; Han, J.; Siomi, M.C. Biogenesis of small RNAs in animals. Nat. Rev. Mol. Cell Biol. 2009, 10, 126-139. [CrossRef]

34. Krol, J.; Loedige, I.; Filipowicz, W. The widespread regulation of microRNA biogenesis, function and decay. Nat. Rev. Genet. 2010, 11, 597-610. [CrossRef] [PubMed]

35. Landgraf, P.; Rusu, M.; Sheridan, R.; Sewer, A.; Iovino, N.; Aravin, A.; Pfeffer, S.; Rice, A.; Kamphorst, A.O.; Landthaler, M.; et al. A Mammalian microRNA Expression Atlas Based on Small RNA Library Sequencing. Cell 2007, 129, 1401-1414. [CrossRef] [PubMed]

36. Elton, T.S.; Sansom, S.E.; Martin, M.M. Trisomy-21 gene dosage over-expression of miRNAs results in the haploinsufficiency of specific target proteins. RNA Biol. 2010, 7, 540-547. [CrossRef]

37. Tarassishin, L.; Loudig, O.; Bauman, A.; Shafit-Zagardo, B.; Suh, H.-S.; Lee, S.C. Interferon regulatory factor 3 inhibits astrocyte inflammatory gene expression through suppression of the proinflammatory miR-155 and miR-155*. Glia 2011, 59, 1911-1922. [CrossRef]

38. Griffiths-Jones, S. The microRNA Registry. Nucleic Acids Res. 2004, 32, D109-D111. [CrossRef]

39. Ciccacci, C.; Latini, A.; Colantuono, A.; Politi, C.; D'Amato, C.; Greco, C.; Rinaldi, M.E.; Lauro, D.; Novelli, G.; Spallone, V.; et al Expression study of candidate miRNAs and evaluation of their potential use as biomarkers of diabetic neuropathy. Epigenomics 2020, 12, 575-585. [CrossRef]

40. Lin, X.; Qin, Y.; Jia, J.; Lin, T.; Lin, X.; Chen, L.; Zeng, H.; Han, Y.; Wu, L.; Huang, S.; et al. MiR-155 Enhances Insulin Sensitivity by Coordinated Regulation of Multiple Genes in Mice. PLoS Genet. 2016, 12, e1006308. [CrossRef]

41. El Samaloty, N.M.; Hassan, Z.A.; Hefny, Z.M.; Abdelaziz, D.H.A. Circulating microRNA-155 is associated with insulin resistance in chronic hepatitis C patients. Arab J. Gastroenterol. 2019, 20, 1-7. [CrossRef] [PubMed]

42. Akhbari, M.; Khalili, M.; Shahrabi-Farahani, M.; Biglari, A.; Bandarian, F. Expression Level of Circulating Cell Free miR-155 Gene in Serum of Patients with Diabetic Nephropathy. Clin. Lab. 2019, 65. [CrossRef] [PubMed]

43. Polina, E.R.; Oliveira, F.M.; Sbruzzi, R.C.; Crispim, D.; Canani, L.H.; Santos, K.G. Gene polymorphism and plasma levels of miR-155 in diabetic retinopathy. Endocr. Connect. 2019, 8, 1591-1599. [CrossRef]

44. Prado, M.S.G.; De Jesus, M.L.; De Goes, T.C.; Mendonça, L.S.O.; Kaneto, C.M. Downregulation of circulating miR-320a and target gene prediction in patients with diabetic retinopathy. BMC Res. Notes 2020, 13, 1-7. [CrossRef]

45. Assmann, T.S.; Recamonde-Mendoza, M.; Puñales, M.; Tschiedel, B.; Canani, L.H.; Crispim, D. MicroRNA expression profile in plasma from type 1 diabetic patients: Case-control study and bioinformatic analysis. Diabetes Res. Clin. Pract. 2018, 141, 35-46. [CrossRef] [PubMed]

46. Bai, X.; Luo, Q.; Tan, K.; Guo, L. Diagnostic value of VDBP and miR-155-5p in diabetic nephropathy and the correlation with urinary microalbumin. Exp. Ther. Med. 2020, 20, 1. [CrossRef]

47. Wang, G.; Wu, B.; Zhang, B.; Wang, K.; Wang, H. LncRNA CTBP1-AS2 alleviates high glucose-induced oxidative stress, ECM accumulation, and inflammation in diabetic nephropathy via miR-155-5p/FOXO1 axis. Biochem. Biophys. Res. Commun. 2020, 532, 308-314. [CrossRef] [PubMed]

48. Corral-Fernández, N.E.; Salgado-Bustamante, M.; Martínez-Leija, M.E.; Espinosa, N.C.; Garcia-Hernandez, M.H.; Hernández, E.R.; Quezada-Calvillo, R.; Portales-Pérez, D.P. Dysregulated miR-155 expression in peripheral blood mononuclear cells from patients with type 2 diabetes. Exp. Clin. Endocrinol. Diabetes 2013, 121, 347-353. [CrossRef]

49. Mazloom, H.; Alizadeh, S.; Pasalar, P.; Esfahani, E.N.; Meshkani, R. Downregulated microRNA-155 expression in peripheral blood mononuclear cells of type 2 diabetic patients is not correlated with increased inflammatory cytokine production. Cytokine 2015, 76, 403-408. [CrossRef]

50. Assmann, T.S.; Duarte, G.C.K.; Brondani, L.A.; De Freitas, P.H.O.; Martins, É.M.; Canani, L.H.; Crispim, D. Polymorphisms in genes encoding miR-155 and miR-146a are associated with protection to type 1 diabetes mellitus. Acta Diabetol. 2017, 54, 433-441. [CrossRef] [PubMed]

51. García-Díaz, D.F.; Pizarro, C.; Camacho-Guillén, P.; Codner, E.; Soto, N.; Pérez-Bravo, F. Expression of miR-155, miR-146a, and miR-326 in T1D patients from Chile: Relationship with autoimmunity and inflammatory markers. Arch. Endocrinol. Metab. 2018, 62, 34-40. [CrossRef]

52. Mostahfezian, M.; Azhir, Z.; Dehghanian, F.; Hojati, Z. Expression Pattern of microRNAs, miR-21, miR-155 and miR-338 in Patients with Type 1 Diabetes. Arch. Med Res. 2019, 50, 79-85. [CrossRef] [PubMed]

53. Yang, T.-T.; Song, S.-J.; Xue, H.-B.; Shi, D.-F.; Liu, C.-M.; Liu, H. Regulatory T cells in the pathogenesis of type 2 diabetes mellitus retinopathy by miR-155. Eur. Rev. Med. Pharmacol. Sci. 2015, 19, 2010-2015. 
54. Hocaoglu, M.; Demirer, S.; Karaalp, I.L.; Kaynak, E.; Attar, E.; Turgut, A.; Karateke, A.; Komurcu-Bayrak, E. Identification of miR-16-5p and miR-155-5p microRNAs differentially expressed in circulating leukocytes of pregnant women with polycystic ovary syndrome and gestational diabetes. Gynecol. Endocrinol. 2021, 37, 216-220. [CrossRef] [PubMed]

55. Elgheznawy, A.; Shi, L.; Hu, J.; Wittig, I.; Laban, H.; Pircher, J.; Mann, A.; Provost, P.; Randriamboavonjy, V.; Fleming, I. Dicer Cleavage by Calpain Determines Platelet microRNA Levels and Function in Diabetes. Circ. Res. 2015, 117, 157-165. [CrossRef] [PubMed]

56. Mazzeo, A.; Beltramo, E.; Lopatina, T.; Gai, C.; Trento, M.; Porta, M. Molecular and functional characterization of circulating extracellular vesicles from diabetic patients with and without retinopathy and healthy subjects. Exp. Eye Res. 2018, 176, 69-77. [CrossRef]

57. Klöting, N.; Berthold, S.; Kovacs, P.; Schön, M.; Fasshauer, M.; Ruschke, K.; Stumvoll, M.; Blüher, M. MicroRNA Expression in Human Omental and Subcutaneous Adipose Tissue. PLoS ONE 2009, 4, e4699. [CrossRef] [PubMed]

58. Kim, N.H.; Ahn, J.; Choi, Y.M.; Son, H.J.; Choi, W.H.; Cho, H.J.; Yu, J.H.; A Seo, J.; Jang, Y.J.; Jung, C.H.; et al. Differential circulating and visceral fat microRNA expression of non-obese and obese subjects. Clin. Nutr. 2020, 39, 910-916. [CrossRef]

59. Huang, Y.; Liu, Y.; Li, L.; Su, B.; Yang, L.; Fan, W.; Yin, Q.; Chen, L.; Cui, T.; Zhang, J.; et al. Involvement of inflammation-related miR-155 and miR-146a in diabetic nephropathy: Implications for glomerular endothelial injury. BMC Nephrol. 2014, 15, 142. [CrossRef]

60. Baker, M.A.; Davis, S.J.; Liu, P.; Pan, X.; Williams, A.M.; Iczkowski, K.A.; Gallagher, S.T.; Bishop, K.; Regner, K.R.; Liu, Y.; et al. Tissue-Specific MicroRNA Expression Patterns in Four Types of Kidney Disease. J. Am. Soc. Nephrol. 2017, 28, $2985-2992$. [CrossRef]

61. Beltrami, C.; Simpson, K.; Jesky, M.; Wonnacott, A.; Carrington, C.; Holmans, P.; Newbury, L.; Jenkins, R.; Ashdown, T.; Dayan, C.; et al. Association of Elevated Urinary miR-126, miR-155, and miR-29b with Diabetic Kidney Disease. Am. J. Pathol. 2018, 188, 1982-1992. [CrossRef]

62. Barutta, F.; Tricarico, M.; Corbelli, A.; Annaratone, L.; Pinach, S.; Grimaldi, S.; Bruno, G.; Cimino, D.; Taverna, D.; Deregibus, M.C.; et al. Urinary Exosomal MicroRNAs in Incipient Diabetic Nephropathy. PLoS ONE 2013, 8, e73798. [CrossRef]

63. Santulli, G.; Pagano, G.; Sardu, C.; Xie, W.; Reiken, S.; D’Ascia, S.L.; Cannone, M.; Marziliano, N.; Trimarco, B.; Guise, T.A.; et al. Calcium release channel RyR2 regulates insulin release and glucose homeostasis. J. Clin. Investig. 2015, 125, 1968-1978. [CrossRef]

64. Ha, J.; Sherman, A. Type 2 diabetes: One disease, many pathways. Am. J. Physiol. Endocrinol. Metab. 2020, 319, E410-E426. [CrossRef]

65. Wysham, C.; Shubrook, J. Beta-cell failure in type 2 diabetes: Mechanisms, markers, and clinical implications. Postgrad. Med. 2020, 132, 676-686. [CrossRef] [PubMed]

66. Nolan, C.J.; Prentki, M. Insulin resistance and insulin hypersecretion in the metabolic syndrome and type 2 diabetes: Time for a conceptual framework shift. Diab. Vasc. Dis. Res. 2019, 16, 118-127. [CrossRef] [PubMed]

67. Esguerra, J.L.S.; Nagao, M.; Ofori, J.K.; Wendt, A.; Eliasson, L. MicroRNAs in islet hormone secretion. Diabetes Obes. Metab. 2018, 20, 11-19. [CrossRef] [PubMed]

68. Halperin, F.; Lopez, X.; Manning, R.; Kahn, C.R.; Kulkarni, R.N.; Goldfine, A.B. Insulin Augmentation of Glucose-Stimulated Insulin Secretion Is Impaired in Insulin-Resistant Humans. Diabetes 2012, 61, 301-309. [CrossRef]

69. Hu, F.B.; Manson, J.E.; Stampfer, M.J.; Colditz, G.; Liu, S.; Solomon, C.G.; Willett, W.C. Diet, Lifestyle, and the Risk of Type 2 Diabetes Mellitus in Women. N. Engl. J. Med. 2001, 345, 790-797. [CrossRef] [PubMed]

70. Chen, C.; Cohrs, C.M.; Stertmann, J.; Bozsak, R.; Speier, S. Human beta cell mass and function in diabetes: Recent advances in knowledge and technologies to understand disease pathogenesis. Mol. Metab. 2017, 6, 943-957. [CrossRef] [PubMed]

71. Ferrannini, E.; Natali, A.; Bell, P.M.; Cavalloperin, P.; Lalic, N.; Mingrone, G. Insulin resistance and hypersecretion in obesity. European Group for the Study of Insulin Resistance (EGIR). J. Clin. Investig. 1997, 100, 1166-1173. [CrossRef]

72. Seltzer, H.S.; Allen, E.W.; Herron, A.L.; Brennan, M.T. Insulin Secretion in Response to Glycemic Stimulus: Relation of Delayed Initial Release to Carbohydrate intolerance in Mild Diabetes Mellitus. J. Clin. Investig. 1967, 46, 323-335. [CrossRef]

73. Lillioja, S.; Mott, D.M.; Spraul, M.; Ferraro, R.; Foley, J.E.; Ravussin, E.; Knowler, W.C.; Bennett, P.H.; Bogardus, C. Insulin Resistance and Insulin Secretory Dysfunction as Precursors of Non-Insulin-Dependent Diabetes Mellitus: Prospective Studies of Pima Indians. N. Engl. J. Med. 1993, 329, 1988-1992. [CrossRef] [PubMed]

74. Camastra, S.; Manco, M.; Mari, A.; Baldi, S.; Gastaldelli, A.; Greco, A.V.; Mingrone, G.; Ferrannini, E. Beta-cell function in morbidly obese subjects during free living: Long-term effects of weight loss. Diabetes 2005, 54, 2382-2389. [CrossRef] [PubMed]

75. Polonsky, K.S.; Given, B.D.; Van Cauter, E. Twenty-four-hour profiles and pulsatile patterns of insulin secretion in normal and obese subjects. J. Clin. Investig. 1988, 81, 442-448. [CrossRef]

76. Perley, M.; Kipnis, D.M. Plasma insulin responses to glucose and tolbutamide of normal weight and obese diabetic and nondiabetic subjects. Diabetes 1966, 15, 867-874. [CrossRef]

77. Brandhorst, H.; Brandhorst, D.; Hering, B.J.; Federlin, K.; Bretzel, R.G. Body Mass Index of Pancreatic Donors: A Decisive Factor for Human Islet Isolation. Exp. Clin. Endocrinol. Diabetes 1995, 103, 23-26. [CrossRef]

78. Yoon, K.H.; Ko, S.H.; Cho, J.H.; Lee, J.M.; Ahn, Y.B.; Song, K.H.; Yoo, S.J.; Kang, M.I.; Cha, B.Y.; Lee, K.W.; et al. Elective beta-cell loss and alpha-cell expansion in patients with type 2 diabetes mellitus in Korea. J. Clin. Endocrinol. Metab. 2003, 88, 2300-2308. [CrossRef] [PubMed] 
79. Hanley, S.C.; Austin, E.; Assouline-Thomas, B.; Kapeluto, J.; Blaichman, J.; Moosavi, M.; Petropavlovskaia, M.; Rosenberg, L. [beta\}-Cell mass dynamics and islet cell plasticity in human type 2 diabetes. Endocrinology 2010, 151, 1462-1472. [CrossRef]

80. Matsumoto, I.; Sawada, T.; Nakano, M.; Sakai, T.; Liu, B.; Ansite, J.D.; Zhang, H.-J.; Kandaswamy, R.; Sutherland, D.E.R.; Hering, B.J. Improvement in Islet Yield from Obese Donors for Human Islet Transplants. Transplantation 2004, 78, 880-885. [CrossRef]

81. Butler, A.E.; Janson, J.; Bonner-Weir, S.; Ritzel, R.; Rizza, R.A.; Butler, P.C. Beta-cell deficit and increased beta-cell apoptosis in humans with type 2 diabetes. Diabetes 2003, 52, 102-110. [CrossRef]

82. Rahier, J.; Guiot, Y.; Goebbels, R.M.; Sempoux, C.; Henquin, J.C. Pancreatic beta-cell mass in European subjects with type 2 diabetes. Diabetes Obes. Metab. 2008, 10, 32-42. [CrossRef]

83. Saisho, Y.; Butler, A.E.; Manesso, E.; Elashoff, D.; Rizza, R.A.; Butler, P.C. Beta-cell mass and turnover in humans: Effects of obesity and aging. Diabetes Care 2013, 36, 111-117. [CrossRef]

84. Sakuraba, H.; Mizukami, H.; Yagihashi, N.; Wada, R.; Hanyu, C. Reduced beta-cell mass and expression of oxidative stress-related DNA damage in the islet of Japanese Type II diabetic patients. Diabetologia 2002, 45, 85-96. [CrossRef] [PubMed]

85. Inaishi, J.; Saisho, Y.; Sato, S.; Kou, K.; Murakami, R.; Watanabe, Y.; Kitago, M.; Kitagawa, Y.; Yamada, T.; Itoh, H. Effects of Obesity and Diabetes on alpha- and beta-Cell Mass in Surgically Resected Human Pancreas. J. Clin. Endocrinol. Metab. 2016, 101, 2874-2882. [CrossRef] [PubMed]

86. Gastaldelli, A.; Ferrannini, E.; Miyazaki, Y.; Matsuda, M.; DeFronzo, R.A. Beta-cell dysfunction and glucose intolerance: Results from the San Antonio metabolism (SAM) study. Diabetologia 2004, 47, 31-39. [CrossRef] [PubMed]

87. Holman, R.R. Assessing the potential for $\alpha$-glucosidase inhibitors in prediabetic states. Diabetes Res. Clin. Pract. 1998, 40, S21-S25. [CrossRef]

88. Jensen, C.C.; Cnop, M.; Hull, R.L.; Fujimoto, W.Y.; Kahn, S.E.; American Diabetes Association GENNID Study Group. Beta-cell function is a major contributor to oral glucose tolerance in high-risk relatives of four ethnic groups in the U.S. Diabetes 2002, 51, 2170-2178. [CrossRef] [PubMed]

89. Ward, W.K.; Bolgiano, D.C.; McKnight, B.; Halter, J.B.; Porte, D. Diminished B cell secretory capacity in patients with noninsulindependent diabetes mellitus. J. Clin. Investig. 1984, 74, 1318-1328. [CrossRef]

90. Ferrannini, E.; Gastaldelli, A.; Miyazaki, Y.; Matsuda, M.; Mari, A.; DeFronzo, R.A. Beta-cell function in subjects spanning the range from normal glucose tolerance to overt diabetes: A new analysis. J. Clin. Endocrinol. Metab. 2005, 90, 493-500. [CrossRef]

91. Osei, K.; Gaillard, T.; Schuster, D.P. Pathogenetic Mechanisms of Impaired Glucose Tolerance and Type II Diabetes in AfricanAmericans: The significance of insulin secretion, insulin sensitivity, and glucose effectiveness. Diabetes Care 1997, $20,396-404$. [CrossRef] [PubMed]

92. Zhu, M.; Zhu, M.; Wei, Y.; Geißler, C.; Abschlag, K.; Corbalán Campos, J.; Hristov, M.; Möllmann, J.; Lehrke, M.; Karshovska, E.; et al . Hyperlipidemia-Induced MicroRNA-155-5p Improves beta-Cell Function by Targeting Mafb. Diabetes 2017, 66, 3072-3084. [CrossRef]

93. Lu, J.; Hamze, Z.; Bonnavion, R.; Herath, N.; Pouponnot, C.; Assade, F.; Fontanière, S.; Bertolino, P.; Cordier-Bussat, M.; Zhang, C.X. Reexpression of oncoprotein MafB in proliferative beta-cells and Men1 insulinomas in mouse. Oncogene 2012, 31, 3647-3654. [CrossRef]

94. Santulli, G.; Lombardi, A.; Sorriento, D.; Anastasio, A.; Del Giudice, C.; Formisano, P.; Béguinot, F.; Trimarco, B.; Miele, C.; Iaccarino, G. Age-related impairment in insulin release: The essential role of beta(2)-adrenergic receptor. Diabetes 2012, 61, 692-701. [CrossRef] [PubMed]

95. Pajvani, U.B.; Accili, D. The new biology of diabetes. Diabetologia 2015, 58, 2459-2468. [CrossRef] [PubMed]

96. Haeusler, R.A.; Hartil, K.; Vaitheesvaran, B.; Arrieta-Cruz, I.; Knight, C.M.; Cook, J.; Kammoun, H.L.; Febbraio, M.A.; GutierrezJuarez, R.; Kurland, I.J.; et al. Integrated control of hepatic lipogenesis versus glucose production requires FoxO transcription factors. Nat. Commun. 2014, 5, 1-8. [CrossRef]

97. Saltiel, A.R.; Kahn, C.R. Insulin signalling and the regulation of glucose and lipid metabolism. Nature 2001, 414, 799-806. [CrossRef] [PubMed]

98. Taha, C.; Klip, A. The insulin signaling pathway. J. Membr. Biol. 1999, 169, 1-12. [CrossRef]

99. Guay, C.; Kruit, J.K.; Rome, S.; Menoud, V.; Mulder, N.L.; Jurdzinski, A.; Mancarella, F.; Sebastiani, G.; Donda, A.; Gonzalez, B.J.; et al. Lymphocyte-Derived Exosomal MicroRNAs Promote Pancreatic beta Cell Death and May Contribute to Type 1 Diabetes Development. Cell Metab. 2019, 29, 348-361.e6. [CrossRef]

100. Flanagan, S.; Haapaniemi, E.; Russell, M.A.; Caswell, R.; Allen, H.L.; De Franco, E.; McDonald, T.; Rajala, H.L.M.; Ramelius, A.; Barton, J.; et al. Activating germline mutations in STAT3 cause early-onset multi-organ autoimmune disease. Nat. Genet. 2014, 46, 812-814. [CrossRef]

101. Yang, X.O.; Panopoulos, A.; Nurieva, R.; Chang, S.H.; Wang, D.; Watowich, S.S.; Dong, C. STAT3 Regulates Cytokine-mediated Generation of Inflammatory Helper T Cells. J. Biol. Chem. 2007, 282, 9358-9363. [CrossRef]

102. Harris, T.J.; Grosso, J.F.; Yen, H.-R.; Xin, H.; Kortylewski, M.; Albesiano, E.; Hipkiss, E.L.; Getnet, D.; Goldberg, M.V.; Maris, C.H.; et al. Cutting Edge: An In Vivo Requirement for STAT3 Signaling in TH17 Development and TH17-Dependent Autoimmunity. J. Immunol. 2007, 179, 4313-4317. [CrossRef]

103. Shao, S.; He, F.; Yang, Y.; Yuan, G.; Zhang, M.; Yu, X. Th17 cells in type 1 diabetes. Cell. Immunol. 2012, 280, 16-21. [CrossRef] [PubMed]

104. Ma, C.; Chew, G.Y.; Simpson, N.; Priyadarshi, A.; Wong, M.; Grimbacher, B.; Fulcher, D.A.; Tangye, S.G.; Cook, M.C. Deficiency of Th17 cells in hyper IgE syndrome due to mutations in STAT3. J. Exp. Med. 2008, 205, 1551-1557. [CrossRef] [PubMed] 
105. Li, P.; Grgurevic, S.; Liu, Z.; Harris, D.; Rozovski, U.; Calin, G.A.; Keating, M.J.; Estrov, Z. Signal Transducer and Activator of Transcription-3 Induces MicroRNA-155 Expression in Chronic Lymphocytic Leukemia. PLoS ONE 2013, 8, e64678. [CrossRef] [PubMed]

106. Escobar, T.; Yu, C.-R.; Muljo, S.A.; Egwuagu, C.E. STAT3 activates miR-155 in Th17 cells and acts in concert to promote experimental autoimmune uveitis. Investig. Ophthalmol. Vis. Sci. 2013, 54, 4017-4025. [CrossRef] [PubMed]

107. Chen, A.; Wen, J.; Lu, C.; Lin, B.; Xian, S.; Huang, F.; Wu, Y.; Zeng, Z. Inhibition of miR-155-5p attenuates the valvular damage induced by rheumatic heart disease. Int. J. Mol. Med. 2019, 45, 429-440. [CrossRef]

108. Mycko, M.P.; Cichalewska, M.; Machlanska, A.; Cwiklinska, H.; Mariasiewicz, M.; Selmaj, K.W. microRNA-301a regulation of a T-helper 17 immune response controls autoimmune demyelination. Proc. Natl. Acad. Sci. USA 2012, 109, E1248-E1257. [CrossRef]

109. Wildin, R.S.; Freitas, A. IPEX and FOXP3: Clinical and research perspectives. J. Autoimmun. 2005, 25, 56-62. [CrossRef]

110. Mohr, A.; Atif, M.; Balderas, R.; Gorochov, G.; Miyara, M. The role of FOXP3+regulatory T cells in human autoimmune and inflammatory diseases. Clin. Exp. Immunol. 2019, 197, 24-35. [CrossRef]

111. Chao, G.; Li, X.; Ji, Y.; Zhu, Y.; Li, N.; Zhang, N.; Feng, Z.; Niu, M. MiR-155 controls follicular Treg cell-mediated humoral autoimmune intestinal injury by inhibiting CTLA-4 expression. Int. Immunopharmacol. 2019, 71, 267-276. [CrossRef] [PubMed]

112. Kohlhaas, S.; Garden, O.A.; Scudamore, C.; Turner, M.; Okkenhaug, K.; Vigorito, E. Cutting Edge: The Foxp3 Target miR-155 Contributes to the Development of Regulatory T Cells. J. Immunol. 2009, 182, 2578-2582. [CrossRef]

113. Schjenken, J.E.; Moldenhauer, L.M.; Zhang, B.; Care, A.; Groome, H.M.; Chan, H.-Y.; Hope, C.M.; Barry, S.; Robertson, S.A MicroRNA miR-155 is required for expansion of regulatory T cells to mediate robust pregnancy tolerance in mice. Mucosal Immunol. 2020, 13, 609-625. [CrossRef] [PubMed]

114. Zhang, J.; Wei, B.; Hu, H.; Liu, F.; Tu, Y.; Zhao, M.; Wu, N. Preliminary study on decreasing the expression of FOXP3 with miR-155 to inhibit diffuse large B-cell lymphoma. Oncol. Lett. 2017, 14, 1711-1718. [CrossRef] [PubMed]

115. Georgantas, R.W., III; Hildreth, R.; Morisot, S.; Alder, J.; Liu, C.-G.; Heimfeld, S.; Calin, G.A.; Croce, C.M.; Civin, C.I. CD34+ hematopoietic stem-progenitor cell microRNA expression and function: A circuit diagram of differentiation control. Proc. Natl. Acad. Sci. USA 2007, 104, 2750-2755. [CrossRef] [PubMed]

116. Vigorito, E.; Perks, K.L.; Abreu-Goodger, C.; Bunting, S.; Xiang, Z.; Kohlhaas, S.; Das, P.P.; Miska, E.A.; Rodriguez, A.; Bradley, A.; et al. microRNA-155 Regulates the Generation of Immunoglobulin Class-Switched Plasma Cells. Immunity 2007, 27, 847-859. [CrossRef]

117. Hu, Y.-L.; Fong, S.; Largman, C.; Shen, W.-F. HOXA9 regulates miR-155 in hematopoietic cells. Nucleic Acids Res. 2010, 38, 5472-5478. [CrossRef]

118. Masaki, S.; Ohtsuka, R.; Abe, Y.; Muta, K.; Umemura, T. Expression patterns of microRNAs 155 and 451 during normal human erythropoiesis. Biochem. Biophys. Res. Commun. 2007, 364, 509-514. [CrossRef] [PubMed]

119. Lu, L.-F.; Thai, T.-H.; Calado, D.; Chaudhry, A.; Kubo, M.; Tanaka, K.; Loeb, G.B.; Lee, H.; Yoshimura, A.; Rajewsky, K.; et al. Foxp3-Dependent MicroRNA155 Confers Competitive Fitness to Regulatory T Cells by Targeting SOCS1 Protein. Immunity 2009, 30, 80-91. [CrossRef] [PubMed]

120. Rodriguez, A.; Vigorito, E.; Clare, S.; Warren, M.V.; Couttet, P.; Soond, D.R.; Van Dongen, S.; Grocock, R.J.; Das, P.P.; Miska, E.A.; et al. Requirement of bic/microRNA-155 for Normal Immune Function. Science 2007, 316, 608-611. [CrossRef]

121. Thai, T.-H.; Calado, D.; Casola, S.; Ansel, K.M.; Xiao, C.; Xue, Y.; Murphy, A.; Frendewey, D.; Valenzuela, D.; Kutok, J.L.; et al. Regulation of the Germinal Center Response by MicroRNA-155. Science 2007, 316, 604-608. [CrossRef]

122. O'Connell, R.M.; Taganov, K.D.; Boldin, M.; Cheng, G.; Baltimore, D. MicroRNA-155 is induced during the macrophage inflammatory response. Proc. Natl. Acad. Sci. USA 2007, 104, 1604-1609. [CrossRef] [PubMed]

123. Tili, E.; Michaille, J.-J.; Cimino, A.; Costinean, S.; Dumitru, C.D.; Adair, B.; Fabbri, M.; Alder, H.; Liu, C.G.; Calin, G.; et al Modulation of miR-155 and miR-125b Levels following Lipopolysaccharide/TNF- $\alpha$ Stimulation and Their Possible Roles in Regulating the Response to Endotoxin Shock. J. Immunol. 2007, 179, 5082-5089. [CrossRef]

124. Ceppi, M.; Pereira, P.M.; Dunand-Sauthier, I.; Barras, E.; Reith, W.; Santos, M.; Pierre, P. MicroRNA-155 modulates the interleukin1 signaling pathway in activated human monocyte-derived dendritic cells. Proc. Natl. Acad. Sci. USA 2009, 106, 2735-2740. [CrossRef]

125. Cremer, T.J.; Ravneberg, D.H.; Clay, C.D.; Piper-Hunter, M.G.; Marsh, C.B.; Elton, T.S.; Gunn, J.S.; Amer, A.; Kanneganti, T.-D.; Schlesinger, L.S.; et al. MiR-155 Induction by F. novicida but Not the Virulent, F. tularensis Results in SHIP Down-Regulation and Enhanced Pro-Inflammatory Cytokine Response. PLoS ONE 2009, 4, e8508. [CrossRef]

126. Mao, C.-P.; He, L.; Tsai, Y.-C.; Peng, S.; Kang, T.H.; Pang, X.; Monie, A.; Hung, C.-F.; Wu, T.-C. in vivo microRNA-155 expression influences antigen-specific T cell-mediated immune responses generated by DNA vaccination. Cell Biosci. 2011, 1, 3. [CrossRef] [PubMed]

127. Koch, M.; Mollenkopf, H.-J.; Klemm, U.; Meyer, T.F. Induction of microRNA-155 is TLR- and type IV secretion system-dependent in macrophages and inhibits DNA-damage induced apoptosis. Proc. Natl. Acad. Sci. USA 2012, 109, E1153-E1162. [CrossRef]

128. Wang, P.; Hou, J.; Lin, L.; Wang, C.; Liu, X.; Li, D.; Ma, F.; Wang, Z.; Cao, X. Inducible microRNA-155 Feedback Promotes Type I IFN Signaling in Antiviral Innate Immunity by Targeting Suppressor of Cytokine Signaling 1. J. Immunol. 2010, 185, 6226-6233. [CrossRef] 
129. Androulidaki, A.; Iliopoulos, D.; Arranz, A.; Doxaki, C.; Schworer, S.; Zacharioudaki, V.; Margioris, A.N.; Tsichlis, P.N.; Tsatsanis, C. The Kinase Akt1 Controls Macrophage Response to Lipopolysaccharide by Regulating MicroRNAs. Immunity 2009, 31, 220-231. [CrossRef] [PubMed]

130. O'Connell, R.M.; Chaudhuri, A.A.; Rao, D.; Baltimore, D. Inositol phosphatase SHIP1 is a primary target of miR-155. Proc. Natl. Acad. Sci. USA 2009, 106, 7113-7118. [CrossRef] [PubMed]

131. Schulte, L.; Westermann, A.; Vogel, J. Differential activation and functional specialization of miR-146 and miR-155 in innate immune sensing. Nucleic Acids Res. 2012, 41, 542-553. [CrossRef] [PubMed]

132. Musilova, K.; Mraz, M. MicroRNAs in B-cell lymphomas: How a complex biology gets more complex. Leukemia 2015, 29, 1004-1017. [CrossRef]

133. Vasilatou, D.; Papageorgiou, S.; Pappa, V.; Papageorgiou, E.; Dervenoulas, J. The role of microRNAs in normal and malignant hematopoiesis. Eur. J. Haematol. 2010, 84, 1-16. [CrossRef]

134. Tili, E.; Croce, C.M.; Michaille, J.-J. miR-155: On the Crosstalk Between Inflammation and Cancer. Int. Rev. Immunol. 2009, 28, 264-284. [CrossRef]

135. Elton, T.S.; Selemon, H.; Elton, S.M.; Parinandi, N.L. Regulation of the MIR155 host gene in physiological and pathological processes. Gene 2013, 532, 1-12. [CrossRef]

136. Leng, R.-X.; Pan, H.-F.; Qin, W.-Z.; Chen, G.-M.; Ye, D.-Q. Role of microRNA-155 in autoimmunity. Cytokine Growth Factor Rev. 2011, 22, 141-147. [CrossRef] [PubMed]

137. Chen, Z.; Ma, T.; Huang, C.; Hu, T.; Li, J. The Pivotal Role of microRNA-155 in the Control of Cancer. J. Cell. Physiol. 2014, 229, 545-550. [CrossRef] [PubMed]

138. Faraoni, I.; Antonetti, F.R.; Cardone, J.; Bonmassar, E. miR-155 gene: A typical multifunctional microRNA. Biochim. Biophys. Acta 2009, 1792, 497-505. [CrossRef] [PubMed]

139. Shah, M.S.; Brownlee, M. Molecular and Cellular Mechanisms of Cardiovascular Disorders in Diabetes. Circ. Res. 2016, 118, 1808-1829. [CrossRef] [PubMed]

140. Sardu, C.; De Lucia, C.; Wallner, M.; Santulli, G. Diabetes Mellitus and Its Cardiovascular Complications: New Insights into an Old Disease. J. Diabetes Res. 2019, 2019, 1-2. [CrossRef]

141. Giacco, F.; Brownlee, M. Oxidative stress and diabetic complications. Circ. Res. 2010, 107, 1058-1070. [CrossRef]

142. Sardu, C.; Marfella, R.; Santulli, G. Impact of Diabetes Mellitus on the Clinical Response to Cardiac Resynchronization Therapy in Elderly People. J. Cardiovasc. Transl. Res. 2014, 7, 362-368. [CrossRef] [PubMed]

143. Yuan, T.; Yang, T.; Chen, H.; Fu, D.; Hu, Y.; Wang, J.; Yuan, Q.; Yu, H.; Xu, W.; Xie, X. New insights into oxidative stress and inflammation during diabetes mellitus-accelerated atherosclerosis. Redox Biol. 2019, 20, 247-260. [CrossRef]

144. Gambardella, J.; Lombardi, A.; Santulli, G. Metabolic Flexibility of Mitochondria Plays a Key Role in Balancing Glucose and Fatty Acid Metabolism in the Diabetic Heart. Diabetes 2020, 69, 2054-2057. [CrossRef] [PubMed]

145. Wilson, S.; Mone, P.; Jankauskas, S.S.; Gambardella, J.; Santulli, G. Chronic kidney disease: Definition, updated epidemiology, staging, and mechanisms of increased cardiovascular risk. J. Clin. Hypertens. 2021, 23, 831-834. [CrossRef] [PubMed]

146. Gaede, P.; Lund-Andersen, H.; Parving, H.-H.; Pedersen, O. Effect of a Multifactorial Intervention on Mortality in Type 2 Diabetes. N. Engl. J. Med. 2008, 358, 580-591. [CrossRef] [PubMed]

147. UK Prospective Diabetes Study (UKPDS) Group. Intensive blood-glucose control with sulphonylureas or insulin compared with conventional treatment and risk of complications in patients with type 2 diabetes (UKPDS 33). Lancet 1998, 352, 837-853. [CrossRef]

148. Webster, A.C.; Nagler, E.V.; Morton, R.L.; Masson, P. Chronic Kidney Disease. Lancet 2017, 389, 1238-1252. [CrossRef]

149. Ferenbach, D.A.; Bonventre, J.V. Acute kidney injury and chronic kidney disease: From the laboratory to the clinic. Nephrol. Ther. 2016, 12, S41-S48. [CrossRef]

150. Tung, C.-W.; Hsu, Y.-C.; Shih, Y.-H.; Chang, P.-J.; Lin, C.-L. Glomerular mesangial cell and podocyte injuries in diabetic nephropathy. Nephrology 2018, 23, 32-37. [CrossRef]

151. Wang, Y.; Zheng, Z.-J.; Jia, Y.-J.; Yang, Y.-L.; Xue, Y.-M. Role of p53/miR-155-5p/sirt1 loop in renal tubular injury of diabetic kidney disease. J. Transl. Med. 2018, 16, 146. [CrossRef]

152. Guo, L.; Tan, K.; Luo, Q.; Bai, X. Dihydromyricetin promotes autophagy and attenuates renal interstitial fibrosis by regulating miR-155-5p/PTEN signaling in diabetic nephropathy. Bosn. J. Basic Med. Sci. 2019, 20, 372-380. [CrossRef]

153. Zhou, Y.; Ma, X.-Y.; Han, J.-Y.; Yang, M.; Lv, C.; Shao, Y.; Wang, Y.-L.; Kang, J.-Y.; Wang, Q.-Y. Metformin regulates inflammation and fibrosis in diabetic kidney disease through TNC/TLR4/NF-kappaB/miR-155-5p inflammatory loop. World J. Diabetes. 2021, 12, 19-46. [CrossRef]

154. Zhang, W.; Li, X.; Tang, Y.; Chen, C.; Jing, R.; Liu, T. miR-155-5p Implicates in the Pathogenesis of Renal Fibrosis via Targeting SOCS1 and SOCS6. Oxidative Med. Cell. Longev. 2020, 2020, 1-11. [CrossRef]

155. Wang, Z.; Chen, R.; Xu, Z.; Ru, W.; Tian, H.; Yang, F.; Tao, C. MiR-155-5p promotes renal interstitial fibrosis in obstructive nephropathy via inhibiting SIRT1 signaling pathway. J. Recept. Signal Transduct. Res. 2020, 2020, 1-10. [CrossRef]

156. Itoh, Y.; Saitoh, M.; Miyazawa, K. Smad3-STAT3 crosstalk in pathophysiological contexts. Acta Biochim. Biophys. Sin. 2017, 50, 82-90. [CrossRef]

157. Meng, X.M.; Nikolic-Paterson, D.J.; Lan, H.Y. TGF-beta: The master regulator of fibrosis. Nat. Rev. Nephrol. 2016, 12, 325-338. [CrossRef] [PubMed] 
158. Rubinsztein, D.C.; Mariño, G.; Kroemer, G. Autophagy and Aging. Cell 2011, 146, 682-695. [CrossRef] [PubMed]

159. Salminen, A.; Kaarniranta, K. SIRT1: Regulation of longevity via autophagy. Cell Signal. 2009, 21, 1356-1360. [CrossRef]

160. Jankauskas, S.S.; Silachev, D.N.; Andrianova, N.V.; Pevzner, I.B.; Zorova, L.D.; Popkov, V.A.; Plotnikov, E.Y.; Zorov, D.B. Aged kidney: Can we protect it? Autophagy, mitochondria and mechanisms of ischemic preconditioning. Cell Cycle 2018, 17, 1291-1309. [CrossRef] [PubMed]

161. Imaizumi, T.; Tanaka, H.; Tajima, A.; Yokono, Y.; Matsumiya, T.; Yoshida, H.; Tsuruga, K.; Aizawa-Yashiro, T.; Hayakari, R.; Inoue, I.; et al. IFN-gamma and TNF-alpha synergistically induce microRNA-155 which regulates TAB2/IP-10 expression in human mesangial cells. Am. J. Nephrol. 2010, 32, 462-468. [CrossRef]

162. Lin, X.; Zhen, X.; Huang, H.; Wu, H.; You, Y.; Guo, P.; Gu, X.; Yang, F. Role of MiR-155 Signal Pathway in Regulating Podocyte Injury Induced by TGF-beta1. Cell Physiol. Biochem. 2017, 42, 1469-1480. [CrossRef]

163. Lin, X.; You, Y.; Wang, J.; Qin, Y.; Huang, P.; Yang, F. MicroRNA-155 Deficiency Promotes Nephrin Acetylation and Attenuates Renal Damage in Hyperglycemia-Induced Nephropathy. Inflammation 2014, 38, 546-554. [CrossRef]

164. Li, Y.; Li, Y.; Duan, J.Z.; He, Q.; Wang, C.Q. miR155 modulates high glucose induced cardiac fibrosis via the Nrf2/HO1 signaling pathway. Mol. Med. Rep. 2020, 22, 4003-4016.

165. Costantino, S.; Paneni, F.; Lüscher, T.F.; Cosentino, F. MicroRNA profiling unveils hyperglycaemic memory in the diabetic heart. Eur. Heart J. 2015, 37, 572-576. [CrossRef] [PubMed]

166. Kertes, P.J.; Johnson, T.M. Evidence-Based Eye Care; Lippincott Williams \& Wilkins: Philadelphia, PA, USA, 2013.

167. Antonetti, D.A.; Silva, P.S.; Stitt, A.W. Current understanding of the molecular and cellular pathology of diabetic retinopathy. Nat. Rev. Endocrinol. 2021, 17, 195-206. [CrossRef] [PubMed]

168. Santulli, R.J.; Kinney, W.A.; Ghosh, S.; Decorte, B.L.; Liu, L.; Tuman, R.W.A.; Zhou, Z.; Huebert, N.; Bursell, S.E.; Clermont, A.C.; et al. Studies with an Orally Bioavailable $\alpha \mathrm{V}$ Integrin Antagonist in Animal Models of Ocular Vasculopathy: Retinal Neovascularization in Mice and Retinal Vascular Permeability in Diabetic Rats. J. Pharmacol. Exp. Ther. 2007, 324, 894-901. [CrossRef] [PubMed]

169. Aggio-Bruce, R.; Chu-Tan, J.A.; Wooff, Y.; Cioanca, A.V.; Schumann, U.; Natoli, R. Inhibition of microRNA-155 Protects Retinal Function Through Attenuation of Inflammation in Retinal Degeneration. Mol. Neurobiol. 2021, 58, 835-854. [CrossRef]

170. Yan, L.; Lee, S.; Lazzaro, D.R.; Aranda, J.; Grant, M.B.; Chaqour, B. Single and Compound Knock-outs of MicroRNA (miRNA)-155 and Its Angiogenic Gene Target CCN1 in Mice Alter Vascular and Neovascular Growth in the Retina via Resident Microglia. J. Biol. Chem. 2015, 290, 23264-23281. [CrossRef]

171. Zhuang, Z.; Qin, X.-; Hu, H.; Tian, S.-Y.; Lu, Z.-J.; Zhang, T.-Z.; Bai, Y.-L. Down-regulation of microRNA-155 attenuates retinal neovascularization via the PI3K/Akt pathway. Mol. Vis. 2015, 21, 1173-1184. [PubMed]

172. Brauer, H.; Strauss, J.; Wegner, W.; Müller-Tidow, C.; Horstmann, M.; Jücker, M. Leukemia-associated mutations in SHIP1 inhibit its enzymatic activity, interaction with the GM-CSF receptor and Grb2, and its ability to inactivate PI3K/AKT signaling. Cell. Signal. 2012, 24, 2095-2101. [CrossRef]

173. Lee, S.; Ahad, A.; Luu, M.; Moon, S.; Caesar, J.; Cardoso, W.V.; Grant, M.B.; Chaqour, B. CCN1-Yes-Associated Protein Feedback Loop Regulates Physiological and Pathological Angiogenesis. Mol. Cell. Biol. 2019, 39. [CrossRef]

174. Park, M.-H.; Kim, A.K.; Manandhar, S.; Koh, G.Y.; Jang, G.-H.; Kang, L.; Lee, D.-W.; Hyeon, D.Y.; Lee, S.-H.; Lee, H.E.; et al. CCN1 interlinks integrin and hippo pathway to autoregulate tip cell activity. eLife 2019, 8. [CrossRef] [PubMed]

175. Kutty, R.K.; Nagineni, C.N.; Samuel, W.; Vijayasarathy, C.; Hooks, J.J.; Redmond, T.M. Inflammatory cytokines regulate microRNA155 expression in human retinal pigment epithelial cells by activating JAK/STAT pathway. Biochem. Biophys. Res. Commun. 2010, 402, 390-395. [CrossRef] [PubMed]

176. Bian, M.; Du, X.; Wang, P.; Cui, J.; Xu, J.; Gu, J.; Zhang, T.; Chen, Y. Combination of ginsenoside Rb1 and Rd protects the retina against bright light-induced degeneration. Sci. Rep. 2017, 7, 6015. [CrossRef]

177. Polack, F.P.; Thomas, S.J.; Kitchin, N.; Absalon, J.; Gurtman, A.; Lockhart, S.; Perez, J.L.; Marc, G.P.; Moreira, E.D.; Zerbini, C.; et al. Safety and Efficacy of the BNT162b2 mRNA Covid-19 Vaccine. N. Engl. J. Med. 2020, 383, 2603-2615. [CrossRef] [PubMed]

178. Baden, L.R.; El Sahly, H.M.; Essink, B.; Kotloff, K.; Frey, S.; Novak, R.; Diemert, D.; Spector, S.A.; Rouphael, N.; Creech, C.B.; et al. Efficacy and Safety of the mRNA-1273 SARS-CoV-2 Vaccine. N. Engl. J. Med. 2021, 384, 403-416. [CrossRef] [PubMed]

179. Fauci, A.S. The story behind COVID-19 vaccines. Sciences 2021, 372, 109. [CrossRef]

180. Gulei, D.; Raduly, L.; Broseghini, E.; Ferracin, M.; Berindan-Neagoe, I. The extensive role of miR-155 in malignant and nonmalignant diseases. Mol. Asp. Med. 2019, 70, 33-56. [CrossRef] 